\title{
Changes in durum wheat root and aerial biomass caused by the introduction of the $R h t-B 1 b$ dwarfing allele and their effects on yield formation
}

\author{
Joan Subira • Karim Ammar • Fanny Álvaro • Luis F. García del Moral • \\ Susanne Dreisigacker $\cdot$ Conxita Royo
}

Received: 31 August 2015 / Accepted: 14 December 2015 / Published online: 27 January 2016

(C) The Author(s) 2016. This article is published with open access at Springerlink.com

\begin{abstract}
Aims This study aimed to quantify the changes in root and aerial biomass of durum wheat brought about by the introduction of the Rht-Blb dwarfing allele and their effects on yield formation.

Methods A historical series of 24 Mediterranean cultivars with allelic variants $a$ (tall) and $b$ (semi-dwarf) at $R h t-B 1$ locus was tested in tubes in three greenhouse experiments and six field experiments.

Results The dwarfing allele reduced the aerial biomass of each plant at anthesis by $7.6 \%$ and the root by $28.1 \%$ (25.4 \%, $26.7 \%$ and $36.0 \%$ in the upper, middle and lower root sections, respectively). Aerial and root biomass were reduced by $27.0 \mathrm{~g} \mathrm{y}^{-1}$ and $7 \mathrm{~g} \mathrm{y}^{-1}$ respectively, but the relative rate of change was much greater for roots $\left(-0.73 \% \mathrm{y}^{-1}\right)$ than for aerial organs $(-0.17 \%$ $\left.\mathrm{y}^{-1}\right)$. Aerial biomass at anthesis was negatively
\end{abstract}

Responsible Editor: Martin Weih.

Electronic supplementary material The online version of this article (doi:10.1007/s11104-015-2781-1) contains supplementary material, which is available to authorized users.

J. Subira · F. Álvaro • C. Royo $(\bowtie)$

IRTA (Institute for Food and Agricultural Research and

Technology), Field Crops Program, 25198 Lleida, Spain

e-mail: conxita.royo@irta.es

K. Ammar $\cdot$ S. Dreisigacker

CIMMYT (International Maize and Wheat Improvement Center), 06600 Mexico, DF, Mexico

\section{F. García del Moral}

Department of Plant Physiology, Faculty of Science, University of Granada, 18071 Granada, Spain associated with spike number, harvest index and yield in tall cultivars, but no significant relationship was found for semi-dwarf ones.

Conclusions The root/aerial biomass ratio was $29 \%$ lower in semi-dwarf than in tall cultivars. In tall cultivars large aerial biomass at anthesis was detrimental to yield formation, while in semi-dwarf cultivars high aerial biomass at anthesis had no effect on yield formation.

Keywords Breeding effects · Genetic gain · Historical series $\cdot$ PVC tubes $\cdot$ Root section

\section{Introduction}

The root system of wheat is essential for firmly anchoring the plant to the soil and taking up water and nutrients from it. In reduced-input agricultural systems, root traits affecting the acquisition of mineral elements often determine yield (Ehdaie et al. 2010; White et al. 2013). In the Mediterranean Basin, one of the largest durum wheat producers in the world, more than $50 \%$ of the total grain of durum wheat is produced in arid and semi-arid conditions, with severe drought most years (Loss and Siddique 1994; Araus et al. 2003; García del Moral et al. 2005). In dryland agricultural systems, a large root system that promotes access to soil water and nutrients is regarded as beneficial for plant growth (Richards 2008), although under terminal drought a greater investment in fine roots at depth would improve yield due to the better access to water and nitrogen (King et al. 2003). Accordingly, root 
dry weight at depth has been related to drought adaptation (Lopes and Reynolds 2010).

The introduction of semi-dwarf cultivars with greater resistance to lodging during the Green Revolution in the second half of the 20th century led to major yield gains (Borlaug 2007). Dwarfness in most durum wheat cultivars is controlled by the Rht-B1b (formerly Rht1) allele. In order to incorporate in durum wheat the dwarfing genes already identified and used in bread wheat, crosses between tall durums and semi-dwarf bread wheats were intensively carried out by Dr. Borlaug's program at CIMMYT from the late 1950's. The varieties 'Langdon enano' and 'Barrigon Yaqui enano' (whose pedigree is YAKTANA-54//NORIN-10/BREVOR/3/ $2 *$ BARRIGON-YAQUI) were the first semi-dwarf durum lines resulting from that crosses (Julio HuertaEspino, pers. Comm.) The objective was to transfer the short and stiff straw character in order to allow the intensification of agronomic practices (increased sowing rate, fertilizer applications and water supply). The Rht$B 1 b$ allele induces insensitiveness to gibberellic acid, thus preventing stem elongation (Peng et al. 1999; Hedden 2003). In addition to the reduced height of the plant, the Rht-B1b allele has well-known pleiotropic effects on plant growth, and morphological and physiological characters (Gale and Youssefian 1985; Li et al. 2011; Rebetzke et al. 2012). It increases yield, mostly under favourable conditions, by altering the proportion of dry matter allocated to grain (De Vita et al. 2007; Royo et al. 2007, 2008; Álvaro et al. 2008a). However, the effect of the Rht-B1b allele on the root system has been poorly explored (Waines and Ehdaie 2007). Previous studies found no consistent association between height genes and root growth and function (Blum 2011). Though the Rht-B1b allele is known to inhibit stem growth, thus making available a surplus of assimilates that are used for thickening the roots (Miralles et al. 1997) without reducing the stem diameter (Calderini et al. 1996), it has been proposed that the enlargement of the root system and its penetration ability might not be under the control of dwarfing genes (Miralles et al. 1997; Kubo et al. 2005). Vigorous shoot growth has been related to vigorous root growth under a wide range of conditions (Mian et al. 1993). However, negative relationships have been identified between root dry weight and plant height in bread wheat (Miralles et al. 1997), and a lower shoot:root ratio has been found in dwarf cultivars (Siddique et al. 1990), seeming to suggest that the selection of cultivars with higher yield and other suitable traits during the 20th century also led to an unintentional selection of those with a reduced investment in root biomass (Zhu and Zhang 2013). Furthermore, modern cultivars containing the $R h t-B 1 b$ allele have shown an increased capacity to take up water in irrigated environments (Pask and Reynolds 2013), thus demonstrating greater efficiency in the use of water after anthesis than the old tall cultivars (Subira et al. 2015).

Quantifying root characteristics in field experiments is a labour-intensive task because the root crop zone is difficult to access (Motzo et al. 1993; Waines and Ehdaie 2007; Izzi et al. 2008; Botwright Acuña and Wade 2012). Therefore, little attention has been devoted to root systems in breeding programmes in the past, most of which have dealt with the above-ground plant organs (Waines and Ehdaie 2007). A number of root observation methods have been proposed, but due to their cost or slowness for routine screening work in breeding programmes, the most widespread among breeders has been the tube method (Blum 2011). The assessment of the root system is essential because water availability is the most limiting factor for the correct expression of yield potential even in irrigated environments, and projections indicate that less usable water will be available in the future (Pask and Reynolds 2013). The tube method is therefore useful for boosting knowledge of the most appropriate root systems for the drought environments that will be more common in the future.

The effect of breeding activities during the 20th century and the introduction of dwarfing alleles on yield, yield components, biomass production and allocation was previously studied by our team on a historical series of 24 Italian and Spanish durum wheat cultivars released in different periods and with different allelic compositions in the Rht-B1 gene (Royo et al. 2007, 2008; Álvaro et al. 2008a, 2008b, 2008c; Subira et al. 2014). The same set of cultivars was used in the present study with the following aims: (i) to quantify the changes occurring in root biomass due to the introduction of the Rht-B1b dwarfing allele, (ii) to determine the relationship between the changes in root biomass and the changes in aerial biomass, and (iii) to study the relationship between biomass and yield formation in tall and semi-dwarf cultivars. Objectives (i) and (ii) were addressed through experiments in PVC tubes under greenhouse conditions, while objective (iii) was addressed using data of field experiments and relating them to those obtained in the greenhouse experiments. 


\section{Materials and methods}

Plant material

The plant material used in this study consisted of a historical series of 24 durum wheat (Triticum turgidum L. var. durum) cultivars selected to represent the germplasm grown in Italy and Spain during the last century (Table 1). The set included tall landraces cultivated before 1945, early semi-dwarf cultivars derived from CIMMYT germplasm such as 'Mexa', landmark early European cultivars such as 'Creso', and cultivars released by local breeding programmes during 1990s in both countries. PCR-based markers specific for the base pair responsible for the semi-dwarf phenotype were used to identify specifically wild-type $(R h t-B 1 a)$ and mutant $(R h t-B 1 b)$ allelic variants at the Rht-B1 locus following the methodology described by Ellis et al. (2002), thus allowing classifying the cultivars into two groups: tall, carrying the Rht$B 1 a$ allele, and semi-dwarf, with the Rht-Blb allele. This methodology confirmed the presence of the $R h t-B 1 b$ allele in the genome of the Italian cultivar 'Adamello', which had previously been considered not to carry any dwarfing allele (Isidro et al. 2011; Álvaro et al. 2008a, 2008b, 2008c; Royo et al. 2007), according to the results of the test for sensitivity to gibberellic acid (Gale and Gregory 1977).
Experiments in tubes in the greenhouse

Three experiments were conducted under greenhouse conditions during three growing seasons at CIMMYT research station in Toluca, State of Mexico $\left(19^{\circ} 16^{\prime} \mathrm{N}\right.$, $\left.99^{\circ} 34^{\prime} \mathrm{W}\right)$. Temperatures and daily photoperiod are shown in Fig. 1. Plants were grown in PVC tubes of $120 \mathrm{~cm}$ height and $10.2 \mathrm{~cm}$ width filled with a soil/sand mixture at a 1:3 ratio and sealed at the bottom with a hole for drainage. Each tube was fertilized with $3.0 \mathrm{~g}$ of urea and $0.5 \mathrm{~g}$ of triple superphospate (TSP), and irrigation was provided periodically to prevent water limitation. Experiments consisted of 72 tubes in 2009 and 2010 and 96 in 2012, arranged in randomized complete block designs with three replications in 2009 and 2010 and four in 2012. Planting dates were 2, 10 and 21 December in 2008, 2009 and 2011, respectively. Three seeds of each cultivar (all of them with a diameter between $2.8 \mathrm{~mm}$ and $3.5 \mathrm{~mm}$ ) were sown in each tube and after seedling emergence only two plants per tube were kept.

At anthesis (Zadoks stage 65, Zadoks et al. 1974) plant height was measured from the soil to the top of the spike excluding the awns, and the entire plants, including the roots, were removed from the tubes (Fig. 2). The roots were carefully washed following the methodology described in Blum (2011) and divided into three sections (upper, middle and lower) of equal length. The aboveground biomass and the three root sections obtained

Table 1 Allelic variant at Rht-B1 locus, name, year of release and country of origin for a historical series of 24 Italian (I) and Spanish (S) durum wheat cultivars

\begin{tabular}{|c|c|c|c|c|c|}
\hline \multicolumn{3}{|c|}{ Tall cultivars $(R h t-B 1 a)$} & \multicolumn{3}{|c|}{ Semi-dwarf cultivars $(R h t-B 1 b)$} \\
\hline Name & Year of release & Country of origin & Name & Year of release & Country of origin \\
\hline Balilla Falso & $<1930$ & I & Creso & 1974 & I \\
\hline Razza 208 & $<1930$ & I & Adamello & 1985 & I \\
\hline Senatore Cappelli & 1930 & I & Simeto & 1988 & I \\
\hline Carlojucci & 1945 & I & Cirillo & 1992 & I \\
\hline Capeiti 8 & 1955 & I & Flavio & 1992 & I \\
\hline Trinakria & 1970 & I & Zenit & 1992 & I \\
\hline Blanco Verdeal & $<1930$ & $\mathrm{~S}$ & Camacho & 1975 & $\mathrm{~S}$ \\
\hline Clarofino & $<1930$ & $\mathrm{~S}$ & Esquilache & 1976 & $\mathrm{~S}$ \\
\hline Pinet & $<1930$ & $\mathrm{~S}$ & Mexa & 1980 & $\mathrm{~S}$ \\
\hline Rubio de Belalcázar & $<1930$ & $\mathrm{~S}$ & Ariesol & 1992 & $\mathrm{~S}$ \\
\hline \multirow[t]{3}{*}{ Bidi 17} & 1950 & $\mathrm{~S}$ & Senadur & 1995 & $\mathrm{~S}$ \\
\hline & & & Astigi & 1999 & $\mathrm{~S}$ \\
\hline & & & Boabdil & 2000 & $\mathrm{~S}$ \\
\hline
\end{tabular}


Fig. 1 Daily photoperiod (dashed line) and indoor minimum (dotted line) and maximum (solid line) daily temperatures during the three years of greenhouse tube experiments at Toluca's research station, CIMMYT (Mexico)
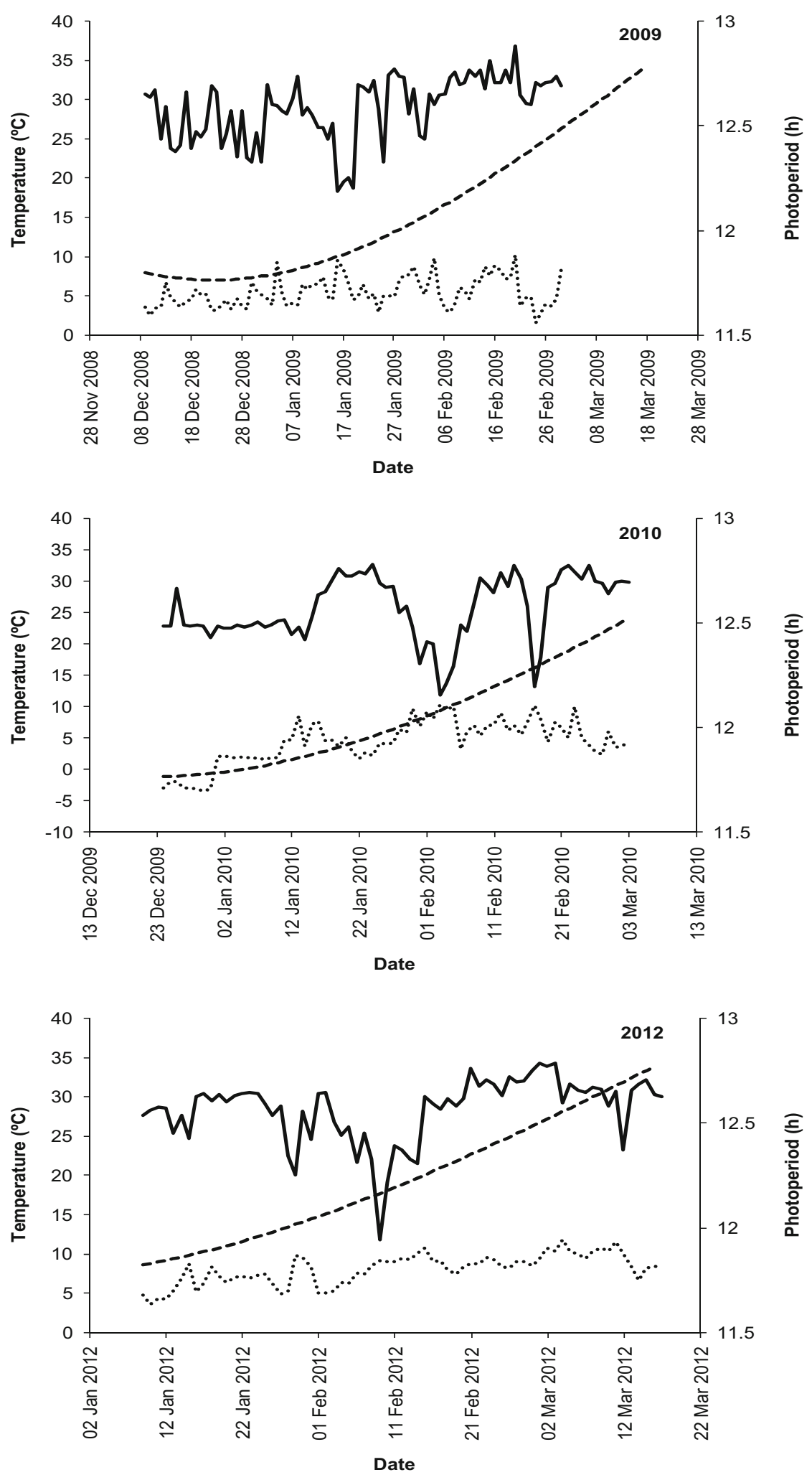

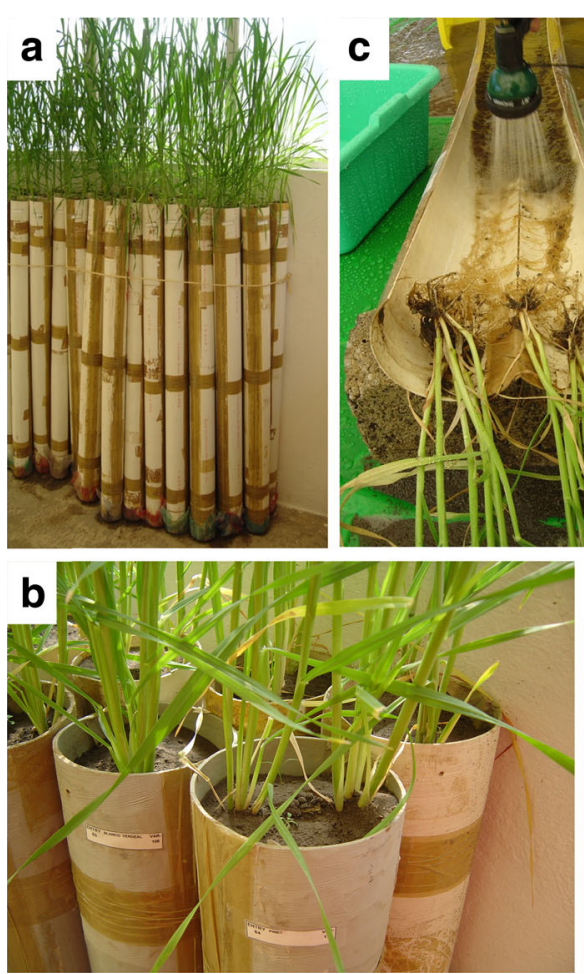

Fig. 2 Methodology used in experiments with tubes in the greenhouse. a PVC tubes with growing wheat plants; $\mathbf{b}$ detail of the growing plants; c-e process of slowly pulling out the roots by

from each tube were oven-dried at $70{ }^{\circ} \mathrm{C}$ for $48 \mathrm{~h}$ and weighed. Dry weight of plant parts was expressed on a single-plant basis.

\section{Field experiments}

Six field experiments were conducted with the same set of cultivars in 2003, 2004 and 2005 at two contrasting sites in Spain: Gimenells in the north-east and Chimeneas in the south (Table 2). Experiments followed randomized complete block designs with three replications and plots of $12 \mathrm{~m}^{2}$ ( 8 rows, $0.15 \mathrm{~m}$ apart). Sowing rate was adjusted to 400 and 350 fully viable seeds per $\mathrm{m}^{2}$ at Gimenells and Chimeneas, respectively. Plots were fertilised following the recommendations for maximizing yields while preventing lodging, and were kept disease- and insect- free with preventive pesticide applications. Anthesis date was recorded for each plot when $50 \%$ of the plants reached this stage and plants within a $50 \mathrm{~cm}$-long row per plot were pulled up at this stage. In
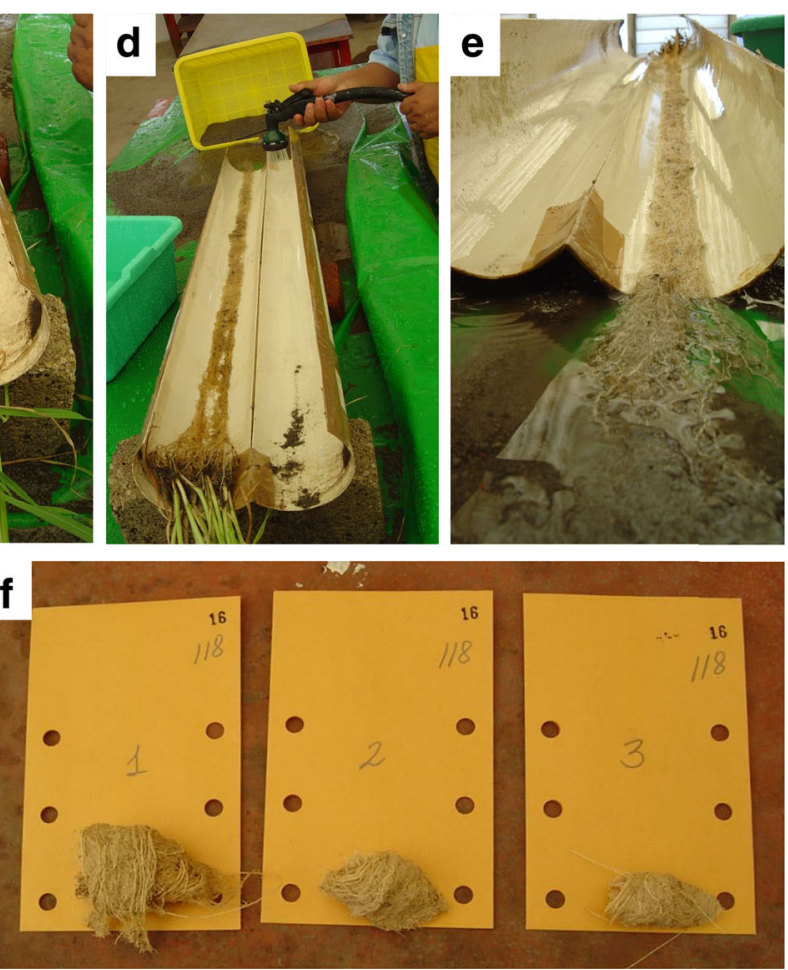

laying down the tubes and carefully washing off all the soil; $\mathbf{f}$ the three sections of the roots of an individual tube before being ovendried

the laboratory the number of plants in each sample was recorded and the plants were oven-dried at $70{ }^{\circ} \mathrm{C}$ for $48 \mathrm{~h}$ to obtain the crop dry weight $\left(\mathrm{CDW}, \mathrm{g}\right.$ per $\mathrm{m}^{2}$ ) and the aerial biomass per plant as the ratio between $\mathrm{CDW}$ and the number of plants per $\mathrm{m}^{2}$. A second 50-cm-long row was randomly sampled at ripening (Zadoks stage 92) on each plot and used to determine the number of spikes per $\mathrm{m}^{2}$ and the number of grains per spike. Harvest index (HI) was obtained on a dry weight basis as the ratio between total grain weight and aboveground biomass of the same sample. The harvest was conducted mechanically at commercial maturity and grain yield was adjusted at $12 \%$ moisture level. Thousand kernel weight was calculated using a subsample of the grain obtained.

\section{Statistical analyses}

Combined ANOVAs were performed across greenhouse experiments considering the experiment, the 
Table 2 Site and description of the six field experiments conducted in this study

\begin{tabular}{|c|c|c|c|c|c|c|}
\hline Site & \multicolumn{3}{|c|}{ Gimenells (North of Spain) } & \multicolumn{3}{|c|}{ Chimeneas (South of Spain) } \\
\hline Coordinates & \multicolumn{3}{|c|}{$41^{\circ} 40^{\prime} \mathrm{N}, 0^{\circ} 20^{\prime} \mathrm{E}$} & \multicolumn{3}{|c|}{$37^{\circ} 08^{\prime} \mathrm{N}, 3^{\circ} 49^{\prime} \mathrm{W}$} \\
\hline Altitude (m asl) & \multicolumn{3}{|l|}{200} & \multicolumn{3}{|l|}{684} \\
\hline Soil texture & \multicolumn{3}{|l|}{ Fine loamy } & \multicolumn{3}{|l|}{ Silty clay } \\
\hline Soil classification & \multicolumn{3}{|c|}{$\begin{array}{l}\text { Mesic calcixerolic } \\
\text { xerochrept }\end{array}$} & \multicolumn{3}{|c|}{$\begin{array}{l}\text { Loamy calcixerolic } \\
\text { xerochrept }\end{array}$} \\
\hline Harvest year & 2003 & 2004 & 2005 & 2003 & 2004 & 2005 \\
\hline Sowing date & 26 Nov 2002 & 16 Dec 2003 & 26 Nov 2004 & 23 Dec 2002 & 13 Nov 2003 & 10 Dec 2004 \\
\hline \multicolumn{7}{|c|}{ Environmental conditions from sowing to anthesis (SA) } \\
\hline $\mathrm{T}_{\mathrm{m}}\left({ }^{\circ} \mathrm{C}\right)$ & 8.64 & 8.13 & 7.24 & 10.7 & 9.81 & 9.43 \\
\hline ETo (mm) & 244 & 206 & 226 & 309 & 290 & 348 \\
\hline RH (\%) & 80.3 & 95.6 & 91.4 & 68.6 & 71.2 & 56.5 \\
\hline WI (rainfall + irrigation, mm) & $170+150$ & $202+85$ & $62.7+150$ & $249+40$ & $334+40$ & $89.8+120$ \\
\hline \multicolumn{7}{|c|}{ Environmental conditions from anthesis to maturity (AM) } \\
\hline $\mathrm{T}_{\mathrm{m}}\left({ }^{\circ} \mathrm{C}\right)$ & 17.6 & 20.0 & 18.8 & 21.3 & 16.2 & 21.1 \\
\hline ETo (mm) & 117 & 140 & 140 & 118 & 139 & 182 \\
\hline $\mathrm{RH}(\%)$ & 78.9 & 87.9 & 85.2 & 45.6 & 66.9 & 38.8 \\
\hline WI (rainfall + irrigation, mm) & $62.5+0$ & $6.03+65$ & $52.9+0$ & 0 & $79.8+0$ & $6.00+0$ \\
\hline Mean yield $\left(\mathrm{kg} \mathrm{ha}^{-1}\right)$ & 5378 & 6495 & 6670 & 2571 & 4327 & 1425 \\
\hline
\end{tabular}

$\mathrm{T}_{\mathrm{m}}$ : average mean daily temperature; ETo: accumulated reference evapotranspiration computed by the Penman-FAO methodology (Allen et al. 1998); RH: average mean daily relative humidity; WI: water input (rainfall + irrigation)

cultivar and their interaction as fixed factors in the model. The sum of squares of the cultivar effect and its interaction were partitioned into differences between alleles at the Rht-B1 locus and differences within each of them. Means were compared with the Student $t$ test $(P=0.05)$. Absolute (AGG) and relative (RGG) genetic gains were computed as the slope of the linear regression line fitted to the relationship between the absolute or relative value of the trait and the year of cultivar release. Relative values were computed for each cultivar as percentages irrespective of the average value of all cultivars. Linear regression models were fitted to the relationships between: i) traits assessed in field experiments, ii) traits assessed in the greenhouse, and iii) biomass assessed in tubes and yield and biomass related traits determined under field conditions. In all cases mean cultivar data across replications and experiments were used. All analyses were performed with the JMP V.8.0 (SAS Institute Inc. 2009) and Enterprise Guide 4.2 statistical software (SAS Institute Inc. 2006).

\section{Results}

Field experiments

Results of the field experiments showing genetic changes in yield, yield components, biomass and $\mathrm{HI}$ have been published elsewhere (Royo et al. 2007, 2008; Álvaro et al. 2008a, 2008b). In this study, the examination of the relationships between yield and its components in terms of biomass production and allocation revealed that, for the whole set of cultivars, grain yield under field conditions

Fig. 3 Relationships between traits assessed in field experiments. Each point corresponds to the mean data of a durum wheat cultivar across six Mediterranean environments and three replications per environment. Relationships between grain yield (y axis) and a aerial biomass per plant at anthesis, b crop dry weight at anthesis, $\mathbf{c}$ harvest index. Relationships between aerial biomass per plant (x axis) and $\mathbf{d}$ harvest index, e number of spikes per $\mathrm{m}^{2}, \mathbf{f}$ number of grains per spike, and $\mathbf{g}$ thousand kernel weight. Black circle Tall cultivars (Rht-B1a), White circle Semi-dwarf cultivars $(R h t-B 1 b)$. Regression equations refer to the models fitted to all cultivars $(n=24)$. Coefficients of determination of linear models fitted to tall $(n=11)$ and semi-dwarf $(n=13)$ cultivars are also shown in each figure. ${ }^{*} P<0.05 ;{ }^{*} P<0.01 ;{ }^{* * *} P<0.001$ 

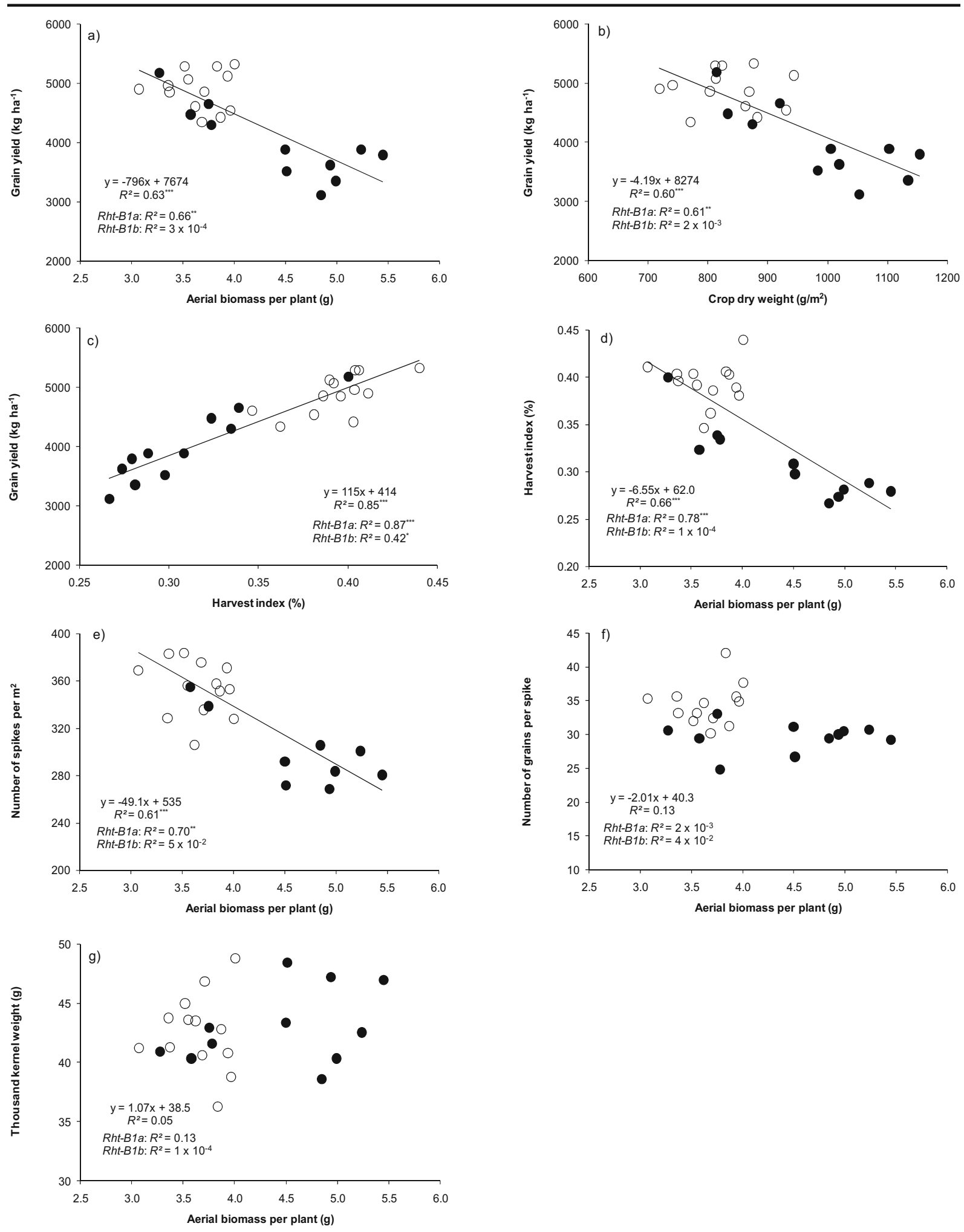
was negatively associated with above-ground biomass at anthesis, determined either at the plant level (Fig. 3a) or at the crop level (Fig. 3b). However, when these relationships were assessed for tall and semi-dwarf cultivars separately they were only significant for the former, which showed greater variability for biomass and also for grain yield (Fig. 3a and 3b). Harvest index was significantly and positively associated with grain yield, and accounted for $85 \%$ of yield variations in the model considering all cultivars (Fig. 3c). This relationship was also significant when semi-dwarf and tall cultivars were measured separately, but its reliability was greater for the latter group. In accordance with these results, aerial biomass per plant at anthesis and $\mathrm{HI}$ were negatively associated, particularly for the set of tall cultivars, but not for the semidwarf ones (Fig. 3d).

The assessment of the relationship between aerial biomass per plant at anthesis and the three main yield components (number of spikes per $\mathrm{m}^{2}$, number of grains per spike and grain weight), showed that for the whole set of cultivars the number of spikes per unit area was negatively associated with aerial biomass per plant at anthesis (Fig. 3e), but no significant relationships were observed between the number of grains per spike and grain weight with aerial biomass per plant at anthesis (Fig. 3f and 3g). This pattern was similar for tall cultivars, while for the semi-dwarf cultivars no significant relationship was found between aerial biomass per plant and any of the three yield components.

\section{Greenhouse experiments}

The results of the ANOVA showed large significant differences between experiments, but negligible differences between replicates within each of them (Table 3). Differences between cultivars were significant for all the traits assessed and always accounted for more than $21 \%$ of total variation. For plant height the cultivar effect explained $67.1 \%$ of total variation. Differences between cultivars carrying and not carrying the $R h t-B 1 b$ allele were also significant for all traits, but for plant height they accounted for $54.5 \%$ of total variation. Variability within the semidwarf cultivars was greater for all traits than the variability within the tall cultivars, except with regard to plant height.

The introduction of the Rht-B1b dwarfing allele had a greater effect on root biomass per plant, which decreased by $28.1 \%$, than on aerial plant biomass, which only decreased by $7.6 \%$ (Table 4). Accordingly, the root/aerial biomass per plant ratio was $28.6 \%$ lower in semi-dwarf cultivars than in tall ones. The lower section of the root, the most distant from the root crown, was the one most altered by the $R h t-B 1 b$ dwarfing allele, as it was reduced by $36 \%$ in the semi-dwarf compared with the tall cultivars, while differences in the upper and middle sections were $25 \%$ and $27 \%$, respectively (Table 4). The distribution of root weight in the three sections was similar in tall and semidwarf cultivars: $52 \%$ and $54 \%$ in the upper section, $26 \%$ and $27 \%$ in the middle section, and $22 \%$ and $19 \%$ in the lower section, respectively (deduced from Table 4).

Among tall cultivars 'Trinakria' showed the lowest values for all the traits assessed in the greenhouse, while 'Blanco Verdeal' had the largest aerial and total biomass per plant and 'Bidi 17' had the largest root biomass per plant and the greatest root/aerial biomass ratio (Supplementary Table 1). The lowest values for root biomass within the semi-dwarf cultivars were recorded for all sections in 'Simeto', which also had the lowest root/aerial biomass ratio. On the other hand, the highest values for all traits except plant height and root biomass in the upper section were recorded in the cultivar 'Camacho'.

Absolute (AGG) and relative (RGG) genetic gains were significant and negative for all traits (Table 5). In absolute terms, the aerial and total biomass per plant decreased at a higher yearly rate than the root biomass. However, in relative terms the decrease was much greater for root biomass $\left(-0.73 \mathrm{~g} \mathrm{y}^{-1}\right)$ than for aerial biomass $\left(-0.17 \mathrm{~g} \mathrm{y}^{-1}\right)$.

Aerial biomass was positively and significantly associated with root biomass, both for the whole root (Fig. 4a) and for each of its sections (Fig. 4b, 4c and 4d). These relationships were also significant when tall and semidwarf cultivars were considered separately, except for the root middle section in tall cultivars (Fig. 4c).

Relationship between traits assessed in tubes in the greenhouse and yield formation

The analysis of the relationship between aerial biomass per plant assessed in tubes and aerial biomass per plant (Fig. 5a) and per unit area (Fig. 5b) in field experiments showed positive and significant associations in all cases when all cultivars were taken. Moreover, the relationship between aerial biomass per plant in tubes and grain yield (Fig. 5c) showed a similar trend to that observed when both traits were assessed in the field (Fig. 3a). Although aerial biomass per plant in tubes was more than three times that recorded in field experiments, both models showed the same tendency and were equally 
Table 3 Percentage of the sum of squares (type III) of the ANOVA for the aboveground and root traits of the 24 durum wheat cultivars of the historical series assessed in three greenhouse experiments

\begin{tabular}{|c|c|c|c|c|c|c|c|c|c|}
\hline \multirow{2}{*}{$\begin{array}{l}\text { Source of } \\
\text { variation }\end{array}$} & \multirow[t]{2}{*}{ d.f. } & \multirow{2}{*}{$\begin{array}{l}\text { Plant } \\
\text { height }\end{array}$} & \multirow{2}{*}{$\begin{array}{l}\text { Aerial } \\
\text { biomass } \\
\text { per plant }(a)\end{array}$} & \multicolumn{4}{|c|}{ Root biomass per plant } & \multirow{2}{*}{$\begin{array}{l}\text { Total biomass } \\
\text { per plant }(a+b)\end{array}$} & \multirow{2}{*}{$\begin{array}{l}\text { Root/aerial } \\
\text { biomass per } \\
\text { plant }(b / a)\end{array}$} \\
\hline & & & & Total $(b)$ & $\begin{array}{l}\text { Upper } \\
\text { section }\end{array}$ & $\begin{array}{l}\text { Middle } \\
\text { section }\end{array}$ & $\begin{array}{l}\text { Lower } \\
\text { section }\end{array}$ & & \\
\hline Experiment & 2 & $13.2^{* * *}$ & $30.2^{* * *}$ & $24.9^{* * *}$ & $23.9^{* * *}$ & $23.4^{* * *}$ & $19.4^{* * *}$ & $30.1^{* * *}$ & $22.1^{* * *}$ \\
\hline Rep (Experiment) & 7 & 0.09 & 1.96 & 1.53 & 2.04 & 1.42 & 1.41 & 1.96 & 1.50 \\
\hline Cultivar & 23 & $67.1^{* * *}$ & $21.2^{* * *}$ & $25.3^{* * *}$ & $23.6^{* * *}$ & $21.8^{* * *}$ & $26.0^{* * *}$ & $22.1^{* * *}$ & $25.8^{* * *}$ \\
\hline Between Rht-B1 & 1 & $54.5^{* * *}$ & $10.8^{* * *}$ & $11.3^{* * *}$ & $8.54^{* * *}$ & $10.3^{* * *}$ & $12.4^{* * *}$ & $11.1^{* * *}$ & $9.97^{* * *}$ \\
\hline Within Rht-B1b & 12 & $5.03^{* * *}$ & $6.02^{* *}$ & $11.6^{* * *}$ & $11.8^{* * *}$ & $9.81^{* * *}$ & 9.71 & $6.95^{* * *}$ & $13.5^{* * *}$ \\
\hline Within Rht-Bla & 10 & $8.14^{* * *}$ & $5.00 * *$ & 3.05 & $3.76^{*}$ & 2.15 & 4.50 & $4.48^{* *}$ & 7.29 \\
\hline Exp x Cultivar & 46 & $10.7^{* * *}$ & $13.7^{*}$ & $17.6^{* * *}$ & $19.9^{* * * *}$ & $16.5^{*}$ & $17.9^{* *}$ & $14.1^{\text {** }}$ & $18.5^{* * * *}$ \\
\hline $\begin{array}{l}\text { Exp x Between } \\
R h t-B 1\end{array}$ & 2 & $3.12^{* * *}$ & $1.99^{* *}$ & $3.64^{* * *}$ & $3.77^{* * *}$ & $2.93^{* *}$ & 4.05 & $2.42^{* *}$ & $3.14^{* * *}$ \\
\hline $\begin{array}{l}\text { Exp x Within } \\
R h t-B 1 b\end{array}$ & 24 & $3.71^{* * *}$ & 4.30 & 5.23 & 6.51 & 6.71 & 5.07 & 4.11 & 2.75 \\
\hline $\begin{array}{l}\text { Exp x Within } \\
\text { Rht-Bla }\end{array}$ & 20 & $4.16^{* * *}$ & $7.30^{*}$ & $8.99^{* * *}$ & $9.80^{* * * *}$ & 6.97 & 9.08 & $7.51^{* *}$ & $8.19^{* *}$ \\
\hline Residual & 161 & 1.98 & 28.2 & 25.6 & 25.1 & 33.2 & 31.7 & 26.9 & 28.1 \\
\hline Total & 239 & & & & & & & & \\
\hline
\end{tabular}

$* P<0.05 ; * * P<0.01 ; * * * P<0.001$

significant for the whole set of cultivars. Similarly, the model fitted to the relationship between aerial biomass per plant measured in tubes and HI determined in the field (Fig. 5d) was similar to that obtained when both traits were determined under field conditions (Fig. 3d). The consistency of all these results led us to examine the relationships between root biomass and both yield (Fig. 5e) and HI (Fig. 5f), which, as expected, were negative in both cases, as occurred for aerial biomass.

\section{Discussion}

Aerial and root biomass in the greenhouse

The great disparity between the data obtained in the three greenhouse experiments was not unexpected considering the differences in the range of temperatures recorded in them. Previous studies demonstrated great experimental variability in root traits under both

Table 4 Mean values across three greenhouse experiments for the aboveground and root traits of tall $(R h t-B 1 a)$ and semi-dwarf $(R h t-B 1 b)$ durum wheat cultivars of the historical series

\begin{tabular}{|c|c|c|c|c|c|}
\hline \multirow[t]{2}{*}{ Trait } & \multicolumn{2}{|c|}{ Rht-B1a } & \multicolumn{2}{|c|}{$R h t-B 1 b$} & \multirow[t]{2}{*}{ Difference $(\%)$} \\
\hline & Mean & Range & Mean & Range & \\
\hline Plant height $(\mathrm{cm})$ & $88.8^{\mathrm{a}}$ & $73.5-108$ & $60.7^{\mathrm{b}}$ & $54.0-75.5$ & -31.6 \\
\hline Aerial biomass per plant $(\mathrm{g})(a)$ & $17.0^{\mathrm{a}}$ & $15.4-17.9$ & $15.7^{b}$ & $15.1-17.2$ & -7.60 \\
\hline Total root biomass per plant $(\mathrm{g})(b)$ & $1.14^{\mathrm{a}}$ & $0.85-1.33$ & $0.82^{b}$ & $0.56-1.28$ & -28.1 \\
\hline Root biomass per plant upper section (g) & $0.59^{\mathrm{a}}$ & $0.43-0.77$ & $0.44^{\mathrm{b}}$ & $0.31-0.66$ & -25.4 \\
\hline Root biomass per plant middle section $(\mathrm{g})$ & $0.30^{\mathrm{a}}$ & $0.25-0.37$ & $0.22^{\mathrm{b}}$ & $0.15-0.34$ & -26.7 \\
\hline Root biomass per plant lower section (g) & $0.25^{\mathrm{a}}$ & $0.17-0.31$ & $0.16^{\mathrm{b}}$ & $0.10-0.29$ & -36.0 \\
\hline Total biomass per plant $(\mathrm{g})(a+b)$ & $18.1^{\mathrm{a}}$ & $16.3-19.2$ & $16.6^{\mathrm{b}}$ & $15.6-18.5$ & -8.29 \\
\hline Root/aerial biomass per plant $(b / a)$ & $0.07^{\mathrm{a}}$ & $0.055-0.079$ & $0.05^{\mathrm{b}}$ & $0.036-0.074$ & -28.6 \\
\hline
\end{tabular}

Means within rows followed by the same letter are not significantly different according to the Student's t test at $P=0.05$ 
Table 5 Absolute (AGG) and relative (RGG, $\% \mathrm{y}^{-1}$ ) genetic changes for the aboveground and root traits of the 24 durum wheat cultivars of the historical series assessed in three greenhouse experiments

\begin{tabular}{|c|c|c|c|c|}
\hline Trait & $R^{2}$ & AGG & RGG & AGG units \\
\hline Aerial biomass per plant $(\mathrm{g})(a)$ & $0.66^{* * *}$ & -27.0 & -0.17 & $g \cdot y^{-1}$ \\
\hline Total root biomass per plant $(\mathrm{g})(b)$ & $0.54^{* * *}$ & -6.99 & -0.73 & $g \cdot y^{-1}$ \\
\hline Root upper section biomass per plant (g) & $0.47^{* * *}$ & -3.42 & -0.67 & $g \cdot y^{-1}$ \\
\hline Root middle section biomass per plant (g) & $0.51^{* * *}$ & -1.68 & -0.67 & $g \cdot y^{-1}$ \\
\hline Root lower section biomass per plant (g) & $0.61^{* * *}$ & -1.83 & -0.90 & $g \cdot y^{-1}$ \\
\hline Total biomass per plant $(\mathrm{g})(a+b)$ & $0.65^{* * *}$ & -34.0 & -0.20 & $g \cdot y^{-1}$ \\
\hline Root/aerial biomass per plant $(b / a)$ & $0.48^{* * *}$ & -0.32 & -0.56 & $\mathrm{y}^{-1}$ \\
\hline
\end{tabular}

$* * * P<0.001$

greenhouse conditions (Botwright Acuña et al. 2007) and field conditions (Botwright Acuña and Wade 2012). However, the results of the three replicates of each
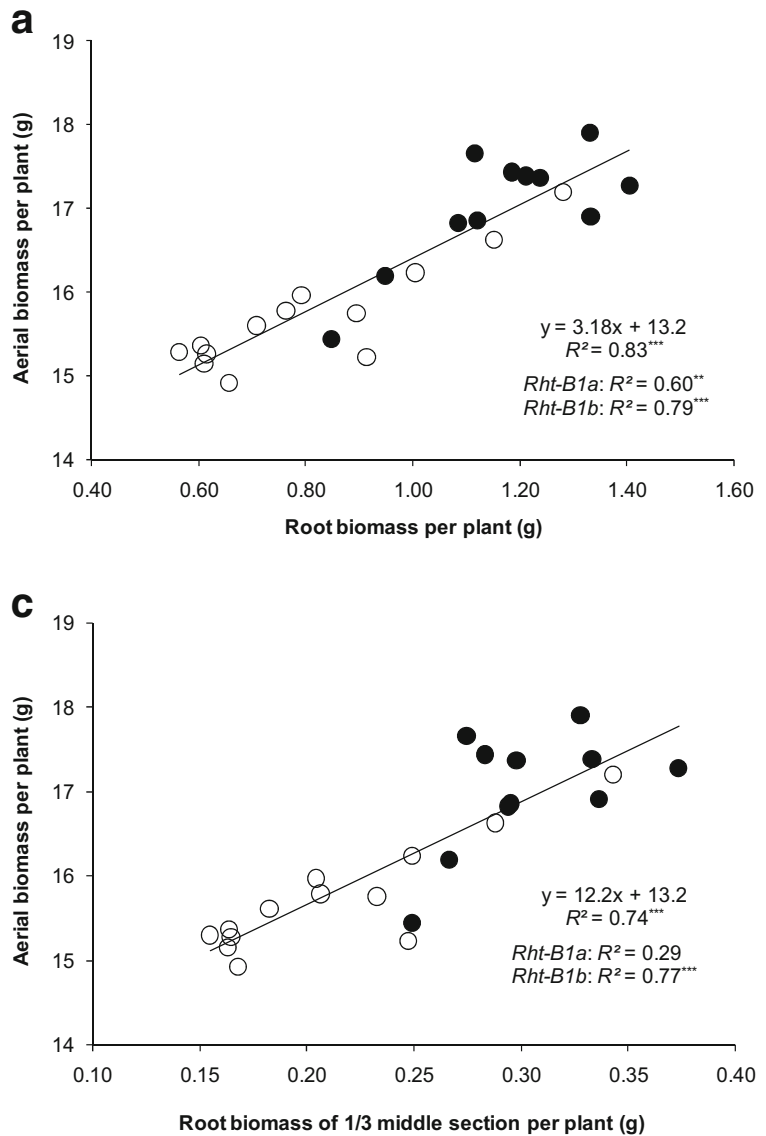

Fig. 4 Relationship between traits assessed for tubes in the greenhouse. Each point corresponds to the mean data of a durum wheat cultivar across three experiments and three (2009 and 2010) or four (in 2012) replications per experiment. Relationships between aerial biomass per plant and $\mathbf{a}$ total root biomass, $\mathbf{b}$ upper $1 / 3$ root section biomass, $\mathbf{c}$ middle $1 / 3$ root section biomass, and $\mathbf{d}$ lower experiment were consistent, as shown by the lack of statistical significance for all traits of the replicate effect (nested to the experiment) of the ANOVA. The
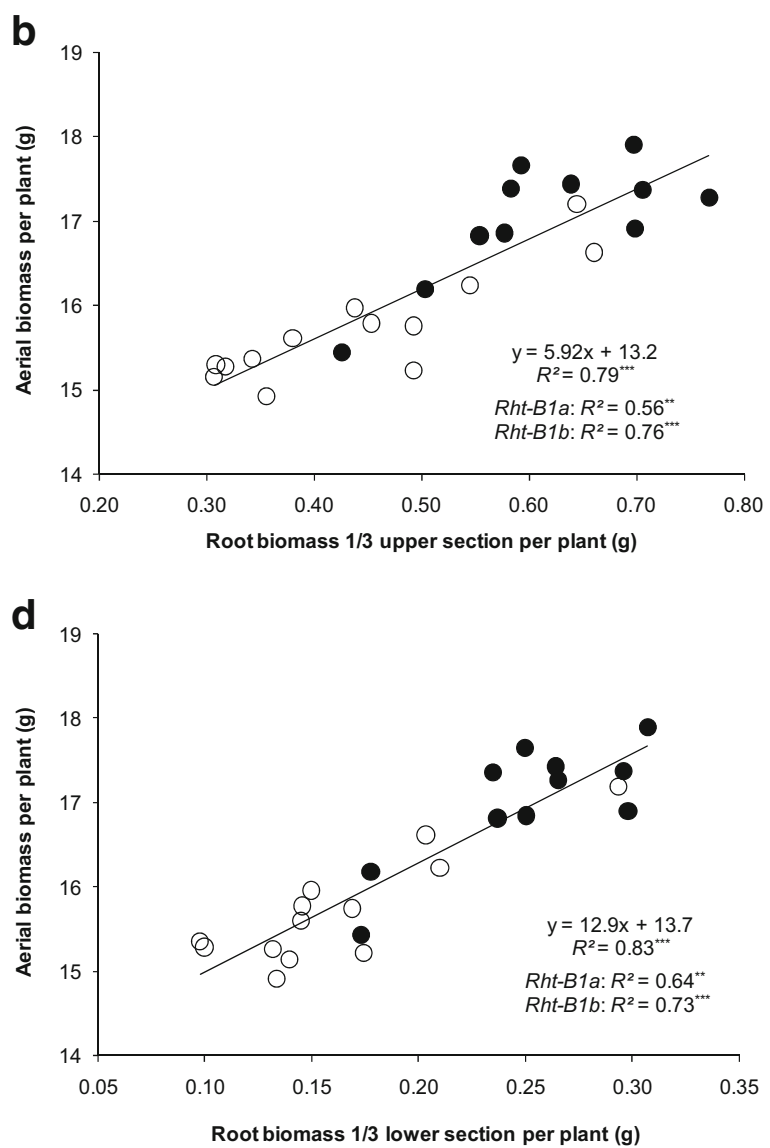

1/3 root section biomass. Black circle Tall cultivars (Rht-B1a), White circle Semi-dwarf cultivars $(R h t-B 1 b)$. Regression equations refer to the models fitted to all cultivars $(n=24)$. Coefficients of determination of linear models fitted to tall $(n=11)$ and semidwarf $(n=13)$ cultivars are also shown on each figure. $* * P<0.01$; $* * * P<0.001$ 
a
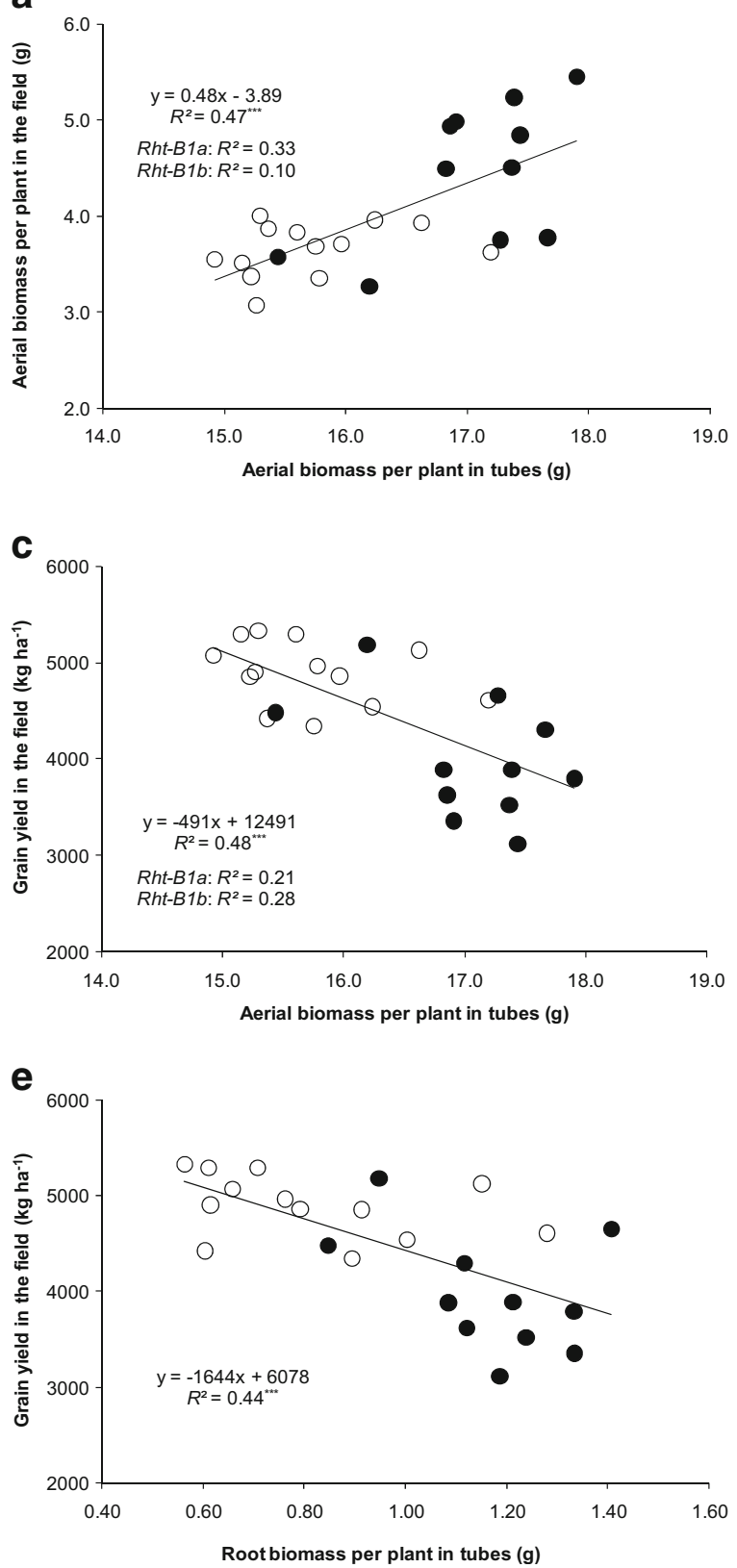

Fig. 5 Relationships between traits assessed for tubes in the greenhouse ( $x$ axis) and traits assessed in the field ( $y$ axis). Relationships between aerial biomass per plant in tubes and a aerial biomass, $\mathbf{b}$ crop dry weight, $\mathbf{c}$ yield and $\mathbf{d}$ harvest index. Relationships between root biomass per plant and e yield and $\mathbf{f}$ harvest index. Each point corresponds to one of 24 durum wheat cultivars.

significance of the cultivar effect for all traits and the high percentage of total variability explained by its sum of squares denoted the wide genetic diversity in the set of cultivars used in the current study. Particularly for plant height, the cultivar effect accounted for ca. $67 \%$ of
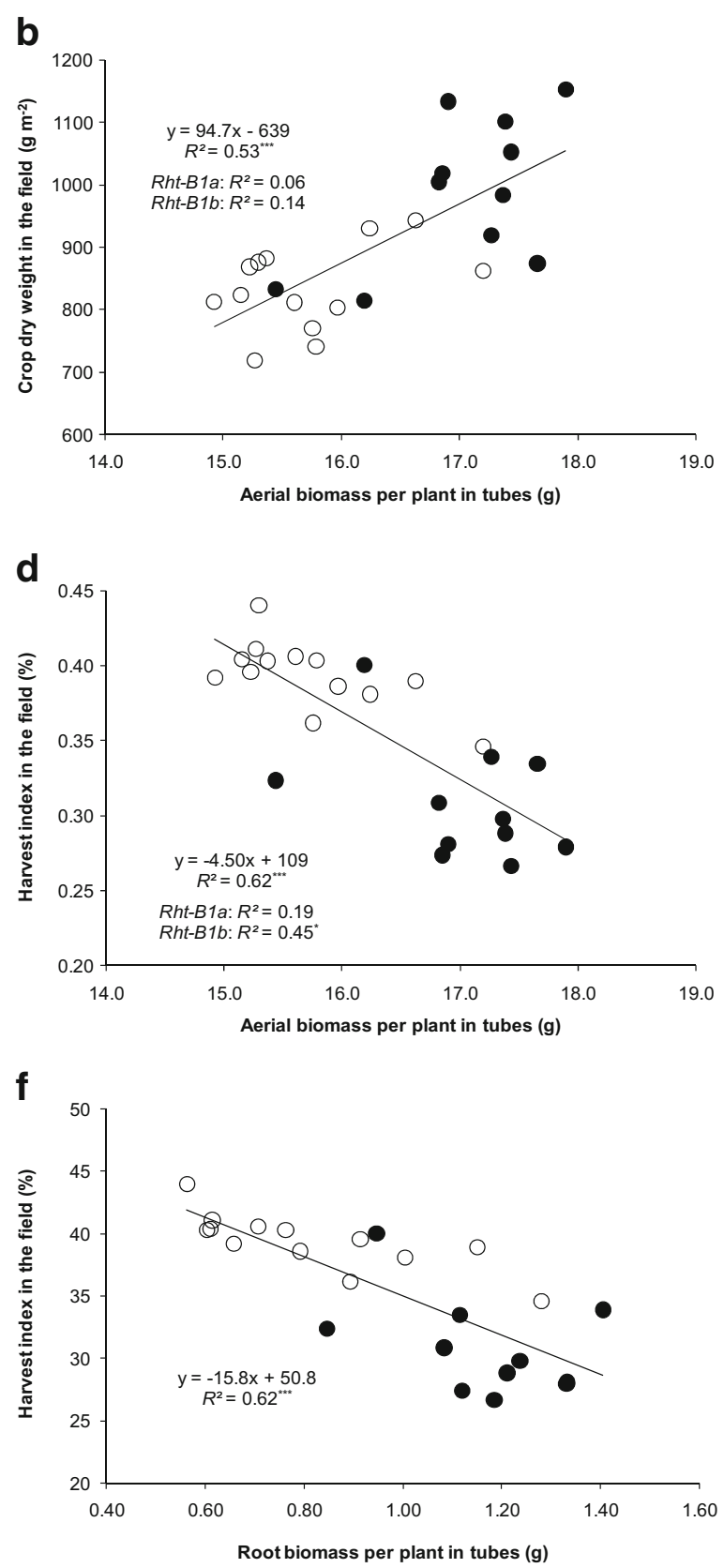

Black circle Tall cultivars (Rht-B1a), White circle Semi-dwarf cultivars $(R h t-B 1 b)$. Regression equations refer to the models fitted to all cultivars $(n=24)$. Coefficients of determination of linear models fitted to tall $(n=11)$ and semi-dwarf $(n=13)$ cultivars are also shown on each figure. $* * * P<0.001$

total variation, and differences between $R h t-B 1$ alleles explained more than $81 \%$ of genotypic variability, thus supporting the importance of plant height in differentiating durum cultivars released before and after the Green Revolution (Royo et al. 2007, 2008; Graybosch 
and Peterson 2010). The greater variability of aerial and root biomass found within semi-dwarf cultivars when compared with tall ones supports the statement that genetic variability was not reduced in modern Mediterranean durum wheat cultivars as a consequence of the breeding activities conducted during the 20th century (Martos et al. 2005).

The significant differences observed in the greenhouse between cultivars carrying the Rht-Bla (tall) and $R h t-B 1 b$ (semi-dwarf) allele for aerial and root biomass indicated that the dwarfing allele not only reduced above-ground biomass, as widely reported by previous studies (Brancourt-Hulmel et al. 2003; Royo et al. 2007; Álvaro et al. 2008a), but also caused a decrease in total root biomass and in each root section. Moreover, the reduction caused by the dwarfing allele in root biomass (ca. $28 \%$ ) was much greater than that observed in aerial biomass (ca. $8 \%$ ), as shown by the relative rate of change, which was more than four times higher for the roots than for the aerial organs $\left(-0.73 \% \mathrm{y}^{-1}\right.$ and $-0.17 \% \mathrm{y}^{-1}$, respectively). Nevertheless, as the aerial fraction of the plant was much heavier than the root fraction, when expressed in absolute terms the genetic change was about four times greater for the aboveground biomass $\left(-27.0 \mathrm{~g} \mathrm{y}^{-1}\right)$ than for the roots $(-7 \mathrm{~g}$ $\left.\mathrm{y}^{-1}\right)$. The relative change in the root/aerial biomass ratio was more than twice that recorded for aerial or total biomass, showing that in relative terms the dwarfing allele had a greater effect on reducing the dry matter of roots than on reducing that of aerial organs. The root/aerial biomass ratio was $29 \%$ lower in semidwarf cultivars than in tall ones. Considering the higher grain yield of the former (Canevara et al. 1994; De Vita et al. 2007; Motzo et al. 2004; Royo et al. 2008), this finding may suggest that cultivars carrying the $R h t-B 1 b$ allele have greater root efficiency for input capture than those carrying the Rht-Bla allele, which is in agreement with the recent proposal of Subira et al. (2015) that semi-dwarf cultivars have an improved capacity to respond to water availability after flowering. In addition, the larger biomass at depth of tall cultivars may denote greater transpiration under drought stress (Blum 2011).

The strong relationship found between root and aerial biomass assessed in tubes was consistent with the reduction caused in both of them by the Rht-B1b dwarfing allele. However, the slope of the linear regression model fitted to the relationship between aerial biomass and biomass of the lower root-section was more than twice the slope of the model fitted to the upper root-section.
This result may indicate that differences between cultivars in root biomass are related to greater differences in aerial biomass when the divergence is due to the lower rather than the upper part of the root.

Relationship between aerial biomass and yield in the field

The results of the study of the relationships between aerial biomass and grain yield under field conditions depended on the specific set of cultivars that were considered when the models were fitted. For the whole set of cultivars, around $60 \%$ of yield variations were explained by differences in the aerial biomass, considered either on a plant or a crop basis, which were negatively associated with yield. Moreover, for the whole set of cultivars $85 \%$ of yield variations were explained by genotypic differences in HI, which had a positive relationship with yield and a negative association with aerial biomass. However, when semi-dwarf and tall cultivars were analysed separately, these relationships were statistically significant only for tall cultivars, suggesting that for this sub-set large biomass at anthesis resulted in low yields, probably due to its negative association with HI. These results indicate that, for the set of cultivars carrying the Rht-Bla allele used in the current study, the maintenance of a large crop biomass competed with the allocation of dry matter in the grain or, in other words, large biomass at anthesis was detrimental for achieving high yields. In contrast, for the set of semi-dwarf cultivars, yield did not depend on the crop biomass at anthesis but was positively associated with HI. These results suggest that, for the set of cultivars carrying the $R h t-B 1 b$ studied here, yield relied on the capacity of the plant to accumulate photosynthates in the grain, independently of the size of the plant canopy at anthesis. It has been demonstrated that one of the greatest effects of the dwarfing allele was the increase in HI, related to the increase in the number of grains per spike and spikelet and an improved translocation efficiency of pre-anthesis assimilates to grains (Royo et al. 2007, 2008; Álvaro et al. 2008b, 2008c).

Differences between tall and semi-dwarf cultivars were also detected when the relationships between aerial biomass and the three main yield components were examined in field experiments. Although both number of grains per spike and grain weight were independent of the plant biomass at anthesis regardless of the set of cultivars considered, for genotypes carrying the $R h t-B 1 a$ 
allele the number of spikes per unit area was negatively associated with aerial biomass, while the two traits were independent for semi-dwarf cultivars. These results may suggest competition in tall cultivars between the investment of resources in enlarging the canopy and the development of reproductive organs. This competition did not seem to exist within semi-dwarf cultivars, probably because their lower plant biomass allowed them to develop a larger number of spikes, as reported by Royo et al. (2007).

Aerial biomass assessed in tubes was positively and significantly associated with that obtained in the field when all cultivars were included in the model, but not for each set independently. These results demonstrate that, although plant development in tubes was much greater than that recorded under field conditions at commercial plant densities, the results obtained in tubes and in the field were properly correlated, but only when the model included a wide range of variability. This assumption was confirmed when similar trends were found in the relationships between yield and aerial biomass assessed in both the field and in tubes, and similar patterns were also obtained for the relationships between $\mathrm{HI}$ and aerial biomass determined by field and tube experiments when all cultivars were included in the model. In order to predict the relationship between root biomass and yield, it was hypothesized that if a significant association existed between the aerial biomass assessed in tubes and in the field for the whole set of cultivars, a relationship would also most likely exist between root biomass in tubes and in field experiments. In accordance with this assumption, the negative associations that appeared between root biomass and both yield and $\mathrm{HI}$ when all cultivars were considered in the model confirm the findings of previous studies regarding the lower efficiency of the biomass of tall varieties in terms of yield formation (Álvaro et al. 2008a, 2008c).

\section{Conclusions}

The introduction of the $R h t-B 1 b$ allele in modern durum wheat cultivars resulted in a reduction in aerial biomass of the plant and an even greater reduction in root biomass along its whole length. A strong and significant positive relationship was found between the aerial and root biomass in the three sections, thus showing that the reduction of the root biomass due to the introduction of the $R h t-B 1 b$ allele occurred in both the upper and the lower parts of the root. Within the tall cultivars, those with large aerial biomass had a lower number of spikes per unit area and also a lower HI, which resulted in yield reductions. On the other hand, within the semi-dwarf cultivars a greater aerial biomass was neither detrimental nor beneficial in terms of yield formation.

Acknowledgments J. Subira was the recipient of a $\mathrm{PhD}$ grant from INIA, Spain. This study was partially funded by projects AGL2002-04285, AGL-2012-37217 and RTA2012-010. Authors thank Dolors Villegas and Julio Isidro for their contribution to the development of experiments.

Open Access This article is distributed under the terms of the Creative Commons Attribution 4.0 International License (http:// creativecommons.org/licenses/by/4.0/), which permits unrestricted use, distribution, and reproduction in any medium, provided you give appropriate credit to the original author(s) and the source, provide a link to the Creative Commons license, and indicate if changes were made.

\section{References}

Allen RG, Pereira LS, Raes D, Smith M (1998) Crop evapotranspiration. Guidelines for computing crop water requirements. Irrigation and drainage paper 56. FAO, Rome

Álvaro F, Isidro J, Villegas D, García del Moral LF, Royo C (2008a) Breeding effects on grain filling, biomass partitioning, and remobilization in Mediterranean durum wheat. Agron J 100:361-370

Álvaro F, Isidro J, Villegas D, García del Moral LF, Royo C (2008b) Old and modern durum wheat varieties from Italy and Spain differ in main spike components. Field Crop Res 106:86-93

Álvaro F, Royo C, García del Moral LF, Villegas D (2008c) Grain filling and dry matter translocation responses to source-sink modifications in a historical series of durum wheat. Crop Sci 48:1523-1531

Araus JL, Bort J, Steduto P, Villegas D, Royo C (2003) Breeding cereals for Mediterranean conditions: ecophysiological clues for biotechnology application. Ann Appl Biol 142:129-141

Blum A (2011) Plant breeding for water-limited environments. Springer, New York

Borlaug NE (2007) Sixty-two years of fighting hunger: personal recollections. Euphytica 157:287-297

Botwright Acuña TL, Wade LJ (2012) Genotype x environment interactions for root depth of wheat. Field Crop Res 137:117-125

Botwright Acuña TL, Pasuquin E, Wade LJ (2007) Genotypic differences in root penetration ability of wheat through thin wax layers in contrasting water regimes and in the field. Plant Soil 301:135-149

Brancourt-Hulmel M, Doussinault G, Lecomte C, Bérard P, Le Buanec B, Trottet M (2003) Genetic improvement of agronomic traits of winter wheat cultivars released in France From 1946 To 1992. Crop Sci 43:37-45 
Calderini DF, Miralles DJ, Sadras VO (1996) Appearance and growth on individual leaves as affected by semidwarfism in isogenic lines of wheat. Ann Bot-London 77:583-589

Canevara MG, Romani M, Corbellini M, Perenzin M, Borghi B (1994) Evolutionary trends in morphological, physiological, agronomical and qualitative traits of Triticum aestivum 1 . cultivars bred in Italy since 1900. Eur J Agron 3:175-185

De Vita P, Li Destri Nicosia O, Nigro F, Platani C, Riefolo C, Di Fonzo N, Cattivelli L (2007) Breeding progress in morpho-physiological, agronomical and qualitative traits of durum wheat cultivars released in Italy during the 20th century. Eur J Agron 26:39-53

Ehdaie B, Merhaut DJ, Ahmadian S, Hoops AC, Khuong T, Layne AP, Waines JG (2010) Root system size influences waternutrient uptake and nitrate leaching potential in wheat. $\mathrm{J}$ Agron Crop Sci 196:455-466

Ellis MH, Spielmeyer W, Gale KR, Rebetzke GJ, Richards RA (2002) "perfect" markers for the Rht-B1b and Rht-D1b dwarfing genes in wheat. Theor Appl Genet 105:1038-1042

Gale MD, Gregory RS (1977) A rapid method for early generation selection of dwarf genotypes in wheat. Euphytica 26:733-738

Gale MD, Youssefian S (1985) Dwarfing genes of wheat. In: Russell GE (ed) Progress in plant breeding. Butterworth and Co, London, pp. 1-35

García del Moral LF, Rharrabti Y, Elhani S, Martos V, Royo C (2005) Yield formation in Mediterranean durum wheats under two contrasting water regimes based on path-coefficient analysis. Euphytica 146:203-212

Graybosch R, Peterson CJ (2010) Genetic improvement in winter wheat yields in the great plains of North America, 19592008. Crop Sci 50:1882-1890

Hedden P (2003) The genes of the green revolution. Trends Genet 19:5-9

Isidro J, Álvaro F, Royo C, Villegas D, Miralles DJ, García del Moral LF (2011) Changes in duration of developmental phases of durum wheat caused by breeding in Spain and Italy during the 20th century and its impact on yield. Ann Bot-London 107:1355-1366

Izzi G, Farahani HJ, Bruggeman A, Oweis TY (2008) In-season wheat root growth and soil water extraction in the Mediterranean environment of Northern Syria. Agr Water Manage 95:259-270

King J, Gay A, Sylvester-Bradley R, Bingham I, Foulkes J, Gregory P, Robinson D (2003) Modelling cereal root systems for water and nitrogen capture: towards an economic optimum. Ann Bot-London 91:383-390

Kubo K, Jitsuyama Y, Iwama K, Watanabe N, Yanagisawa A, Elouafi I, Nachit MM (2005) The reduced height genes do not affect the root penetration ability in wheat. Euphytica 141:105-111

Li P, Chen J, Wu P, Zhang J, Chu C, See D, Brown-Guedira G, Zemetra R, Souza E (2011) Quantitative trait loci analysis for the effect of $R h t-B 1$ dwarfing Gene on coleoptile length and seedling root length and number of bread wheat. Crop Sci 51:2561-2568

Lopes MS, Reynolds MP (2010) Partitioning of assimilates to deeper roots is associated with cooler canopies and increased yield under drought in wheat. Funct Plant Biol 37:147-156

Loss SP, Siddique KHM (1994) Morphological and physiological traits associated with wheat yield increases in Mediterranean environments. Adv Agron 52:229-276

Martos V, Royo C, Rharrabti Y, Garcia del Moral LF (2005) Using AFLPs to determine phylogenetic relationships and genetic erosion in durum wheat cultivars released in Italy and Spain throughout the 20th century. Field Crop Res 91:107-116

Mian MAR, Nafziger ED, Kolb FL, Teyker RH (1993) Root growth of wheat genotypes in hydroponic culture and in the greenhouse under different soil moisture regimes. Crop Sci 33:283-286

Miralles DJ, Slafer GA, Lynch V (1997) Rooting patterns in nearisogenic lines of spring wheat for dwarfism. Plant Soil 197: $79-86$

Motzo R, Attene G, Deidda M (1993) Genotypic variation in durum wheat root systems at different stages of development in a Mediterranean environment. Euphytica 66:197-206

Motzo R, Fois S, Giunta F (2004) Relationship between grain yield and quality of durum wheats from different eras of breeding. Euphytica 140:147-154

Pask AJD, Reynolds MP (2013) Breeding for yield potential has increased deep soil water extraction capacity in irrigated wheat. Crop Sci 53:2090-2104

Peng J, Richards DE, Hartley NM, Murphy GP, Devos KM, Flintham JE, Beales J, Fish LJ, Worland AJ, Pelica F, Sudhakar D, Christou P, Snape JW, Gale MD, Harberd NP (1999) 'Green revolution' genes encode mutant gibberellin response modulators. Nature 400:256-261

Rebetzke GJ, Bonnet DG, Ellis MH (2012) Combining gibberellic acid-sensitive and insensitive dwarfing genes in breeding of higher-yielding, sesqui-dwarf wheats. Field Crop Res 127:17-25

Richards RA (2008) Genetic opportunities to improve cereal root systems for dry-land agriculture. Plant Prod Sci 11:12-16

Royo C, Álvaro F, Martos V, Ramdani A, Isidro J, Villegas D, García del Moral LF (2007) Genetic changes in durum wheat yield components and associated traits in Italian and Spanish varieties during the 20th century. Euphytica 155:259-270

Royo C, Martos V, Ramdani A, Villegas D, Rharrabti Y, García del Moral LF (2008) Changes in yield and carbon isotope discrimination of Italian and Spanish durum wheat during the 20th century. Agron J 100:352-360

SAS (2006) SAS Enterprise Guide 4.2 SAS Institute Inc, Cary

SAS (2009) SAS JMP 8.0 SAS Institute Inc, Cary

Siddique KHM, Belford RK, Tennant D (1990) Root: shoot ratios of old and modern, tall and semi-dwarf wheats in a Mediterranean environment. Plant Soil 121:89-98

Subira J, Peña RJ, Álvaro F, Ammar K, Ramdani A, Royo C (2014) Breeding progress in the pasta-making quality of durum wheat cultivars released in Italy and Spain during the 20th century. Crop Pasture Sci 65:16-26

Subira J, Álvaro F, García del Moral LF, Royo C (2015) Breeding effects on the cultivar $\mathrm{x}$ environment interaction of durum wheat yield. Eur J Agron 68:78-88

Waines JG, Ehdaie B (2007) Domestication and crop physiology: roots of green-revolution wheat. Ann BotLondon 100:991-998

White PJ, George TS, Gregory PJ, Bengough AG, Hallett PD, McKenzie BM (2013) Matching roots to their environment. Ann Bot-London 112:207-222

Zadoks JC, Chang TT, Konzak CF (1974) A decimal code for the growth stages of cereals. Weed Res 14:415-421

Zhu L, Zhang D-Y (2013) Donald's ideotype and growth redundancy: a pot experimental test using and old and a modern spring wheat cultivar. PLoS one 8. doi:10.1371/journal.pone. 0070006 